NASA/TM-2003-212479

\title{
Vibration Modal Characterization of a Stirling Convertor via Base-Shake Excitation
}

Vicente J. Suárez, Thomas W. Goodnight, and William O. Hughes Glenn Research Center, Cleveland, Ohio

Sergey Samorezov

ZIN Technologies, Inc., Cleveland, Ohio 
Since its founding, NASA has been dedicated to the advancement of aeronautics and space science. The NASA Scientific and Technical Information (STI) Program Office plays a key part in helping NASA maintain this important role.

The NASA STI Program Office is operated by Langley Research Center, the Lead Center for NASA's scientific and technical information. The NASA STI Program Office provides access to the NASA STI Database, the largest collection of aeronautical and space science STI in the world. The Program Office is also NASA's institutional mechanism for disseminating the results of its research and development activities. These results are published by NASA in the NASA STI Report Series, which includes the following report types:

- $\quad$ TECHNICAL PUBLICATION. Reports of completed research or a major significant phase of research that present the results of NASA programs and include extensive data or theoretical analysis. Includes compilations of significant scientific and technical data and information deemed to be of continuing reference value. NASA's counterpart of peerreviewed formal professional papers but has less stringent limitations on manuscript length and extent of graphic presentations.

- TECHNICAL MEMORANDUM. Scientific and technical findings that are preliminary or of specialized interest, e.g., quick release reports, working papers, and bibliographies that contain minimal annotation. Does not contain extensive analysis.

- CONTRACTOR REPORT. Scientific and technical findings by NASA-sponsored contractors and grantees.
- CONFERENCE PUBLICATION. Collected papers from scientific and technical conferences, symposia, seminars, or other meetings sponsored or cosponsored by NASA.

- SPECIAL PUBLICATION. Scientific, technical, or historical information from NASA programs, projects, and missions, often concerned with subjects having substantial public interest.

- TECHNICAL TRANSLATION. Englishlanguage translations of foreign scientific and technical material pertinent to NASA's mission.

Specialized services that complement the STI Program Office's diverse offerings include creating custom thesauri, building customized databases, organizing and publishing research results ... even providing videos.

For more information about the NASA STI Program Office, see the following:

- Access the NASA STI Program Home Page at http://www.sti.nasa.gov

- E-mail your question via the Internet to help@sti.nasa.gov

- Fax your question to the NASA Access Help Desk at 301-621-0134

- Telephone the NASA Access Help Desk at 301-621-0390

- Write to:

NASA Access Help Desk

NASA Center for AeroSpace Information 7121 Standard Drive

Hanover, MD 21076 
NASA/TM-2003-212479

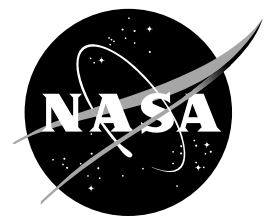

\section{Vibration Modal Characterization of a Stirling Convertor via Base-Shake Excitation}

Vicente J. Suárez, Thomas W. Goodnight, and William O. Hughes Glenn Research Center, Cleveland, Ohio

Sergey Samorezov

ZIN Technologies, Inc., Cleveland, Ohio

Prepared for the

First International Energy Conversion Engineering Conference cosponsored by the American Institute of Aeronautics and Astronautics (AIAA), the American Society of Mechanical Engineers (ASME), and the Institute of Electrical and Electronics Engineers (IEEE)

Portsmouth, Virginia, August 17-21, 2003

National Aeronautics and

Space Administration

Glenn Research Center 
Available from

NASA Center for Aerospace Information 7121 Standard Drive

Hanover, MD 21076
National Technical Information Service 5285 Port Royal Road Springfield, VA 22100

Available electronically at http://gltrs.grc.nasa.gov 


\title{
Vibration Modal Characterization of a Stirling Convertor via Base-Shake Excitation
}

\author{
Vicente J. Suárez, Thomas W. Goodnight, William O. Hughes* \\ National Aeronautics and Space Administration \\ Glenn Research Center \\ Cleveland, Ohio 44135 \\ Sergey Samorezov \\ ZIN Technologies, Inc. \\ Cleveland, Ohio
}

\begin{abstract}
The U.S. Department of Energy (DOE), Lockheed Martin (LM), Stirling Technology Company (STC), and NASA John H. Glenn Research Center (GRC) are currently developing a high-efficiency Stirling convertor for use in a Stirling Radioisotope Generator (SRG). NASA and DOE have identified the SRG for potential use as an advanced power system for future NASA Space Science missions, providing spacecraft onboard electric power for deep space missions and power for unmanned Mars rovers. Low-level, baseshake sine vibration tests were conducted on the Stirling Technology Demonstration Convertor (TDC), at NASA GRC's Structural Dynamics Laboratory, in February 2001, as part of the development of this Stirling technology. The purpose of these tests was to provide a better understanding of the TDC's internal dynamic response to external vibratory base excitations. The knowledge obtained can therein be used to help explain the success that the TDC enjoyed in its previous random vibration qualification tests (December 1999). This explanation focuses on the TDC's internal dynamic characteristics in the 50 to $250 \mathrm{~Hz}$ frequency range, which corresponds to the maximum input levels of its qualification random vibration test specification. The internal dynamic structural characteristics of the TDC have now been measured in two separate tests under different motoring and dynamic loading conditions: (1) with the convertor being electrically motored, under a vibratory base-shake excitation load, and (2) with the convertor turned off, and its alternator internals undergoing dynamic excitation via hammer impact loading. This paper addresses the test setup, procedure and results of the base-shake vibration testing conducted on the motored TDC, and will compare these results with those results obtained from the dynamic impact tests (May 2001) on the nonmotored TDC.
\end{abstract}

*Associate Fellow, AIAA

\section{INTRODUCTION}

The U.S. Department of Energy (DOE), Lockheed Martin (LM), and Stirling Technology Company (STC) in conjunction with NASA John H. Glenn Research Center (GRC) are currently developing a Stirling convertor for use in an advanced radioisotope power system to provide spacecraft on-board electric power for NASA's deep-space missions and for Mars surface rovers. STC of Kennewick, WA is under contract to DOE to develop a radioisotope Stirling convertor. NASA GRC is providing technical consultation for this effort based on their expertise in Stirling technologies dating back to the mid-1970's.

The Stirling system is an attractive alternative to Radioisotope Thermoelectric Generators (RTGs). Due to the Stirling system's efficiency (over 20 percent), just one-fourth of the amount of Plutonium is required compared to the RTGs, thereby significantly reducing radioisotope cost, radioisotope usage, and system cost. ${ }^{1}$

In preparation for possible deep space missions, an operating (power-producing) 55-We (electric watt) Technology Demonstration Convertor (TDC) was dynamically tested in December 1999 at NASA GRC's Structural Dynamics Lab (SDL)., 3 This TDC was tested to levels beyond those used to vibration qualify the comparable RTGs used on the Cassini Mission. Subsequent emissions testing of two TDC's in tandem was also performed to characterize the structure borne disturbances produced by the TDC, and thereby establish vibratory compatibility requirements for possible nearby scientific hardware. The effects of Stirling power package dynamics were studied in both the random qualification and vibratory emissions testing.

TDC design robustness was demonstrated in the December 1999 vibration qualification testing. The physical construction of the TDC in its multi-layered configuration is a primary source of the TDC's robustness. The mounting configuration may also have 
contributed. The linear alternator is the heaviest component of the TDC and is overhung off the piston housing as shown in Figure 1. The large diameter flange of the piston housing was mounted to the rigid fixture in the December 1999 vibration qualification test.

To gain insight to the dynamics of the Stirling TDC a base-shake vibration modal survey of a motored TDC (Unit \#6) was performed, in February 2001. Based on lessons learned, a follow-on impact test was also performed on the non-operating TDC (Unit \#6) in May 2001.

This paper addresses the test setup, procedure and results of the base-shake sine vibration testing conducted on the Stirling TDC. It also draws a comparison between the results of this sine testing and those results obtained from dynamic hammer impact testing.

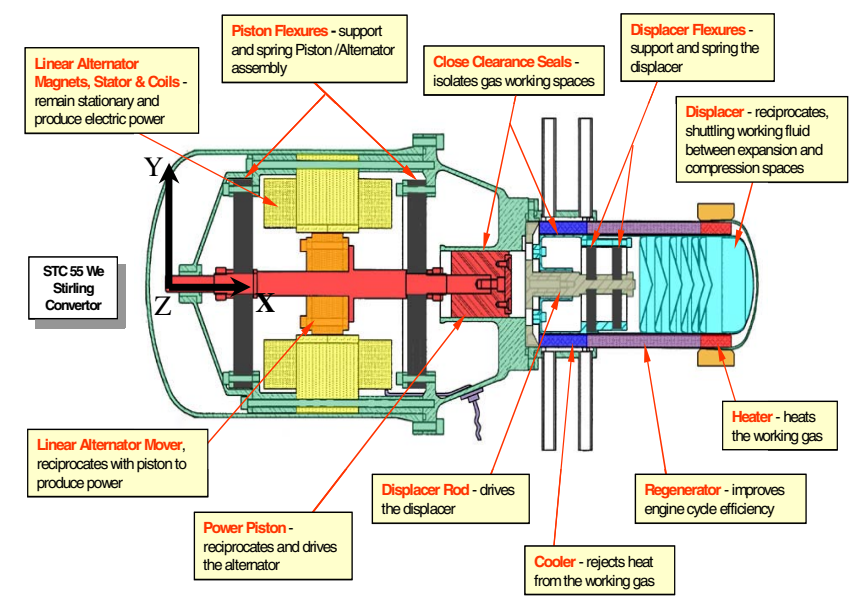

FIGURE 1. Major Components and Functions of the Stirling TDC.

\section{TEST OBJECTIVE}

In the December 1999 vibration qualification testing, the Stirling TDC showed some decreases in power at the maximum excitation levels during the lateral testing (Y-axis) specifically at high test levels ${ }^{2,3}$ (see Figure 2). The TDC returned to full power after the random excitation levels were stopped. The purpose of the February 2001 base-shake vibration model characterization tests was to provide a better understanding of the results obtained in the December 1999 test by identifying the dynamic structural characteristics of the Stirling TDC. Of utmost importance was the description of the predominant structural frequencies of the TDC in the excitation plateau frequency range (50 to $250 \mathrm{~Hz}$ ) of the Design/Qualification specification.

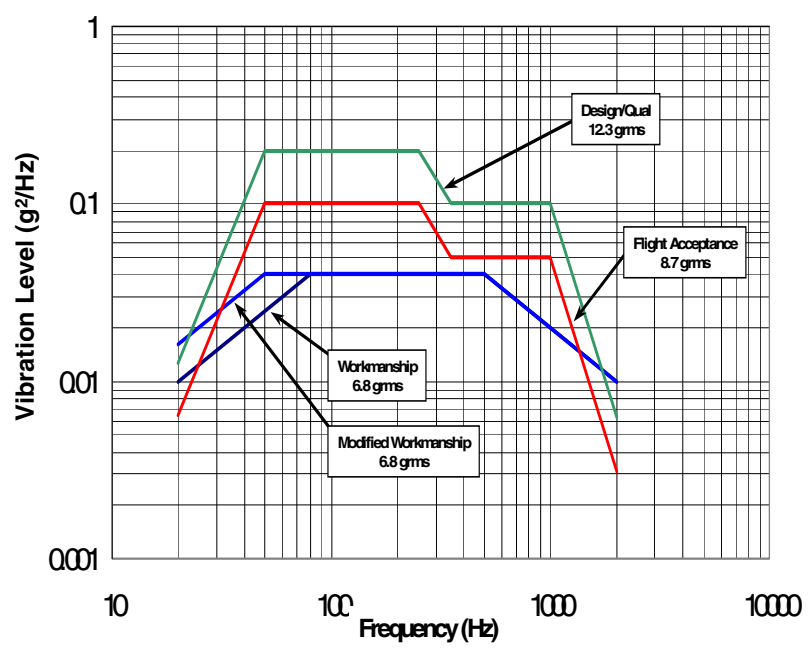

FIGURE 2. Stirling TDC Random Vibration Test Levels (December 1999).

\section{TEST SETUP AND DESCRIPTION}

The Stirling TDC was supported in a specially made test fixture. The test fixture was rigidly mounted to the 60 inch by 72-inch slip table ( $~ 500$ lbs. without test article) as shown in Figure 3. An auxiliary fixture was also built to support instrumentation only. The TDC was not attached to the auxiliary fixture. Similar to the December 1999 vibration qualification test the large diameter flange of the Stirling's piston housing was mounted to the rigid fixture in the February 2001 baseshake vibration test (and in the May 2001 impact test).

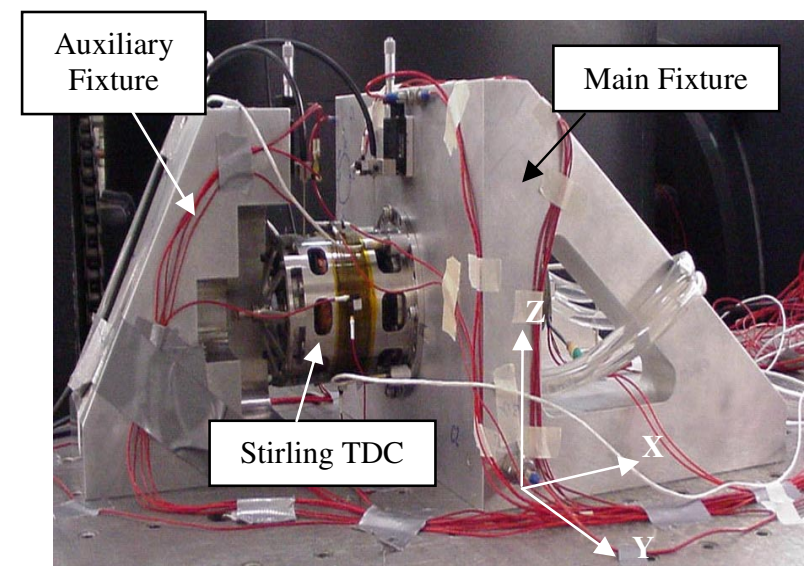

FIGURE 3. Stirling TDC and Test Fixtures.

A total of twenty-nine accelerometers (Endevco 2271, 23, 2222 and 2226) were placed on the Stirling TDC and fixtures (see Table 1). Based on engineering judgment seventeen accelerometers were selected to capture the dynamic behavior of the Stirling TDC and the remaining twelve accelerometers were mounted on 
the fixtures to capture the fixtures' response to the vibration input. Four optical displacement probes were also utilized to capture the Piston/Mover Rod's Y and Z movement with respect to the fixture.

TABLE 1. Location of the Sensors for Base-Shake Vibration Test.

\begin{tabular}{|c|c|c|}
\hline $\begin{array}{c}\text { Node } \\
\#\end{array}$ & Label & Location \\
\hline 1 & $\mathrm{C} 1 *$ & Main Fixture \\
\hline 2 & $\mathrm{C} 2 *$ & Main Fixture \\
\hline 3 & $\begin{array}{l}3 \mathrm{X}-* \\
3 \mathrm{Y}-* \\
3 \mathrm{Z}-*\end{array}$ & $\begin{array}{l}\text { Outboard End of } \\
\text { Piston/Mover Rod }\end{array}$ \\
\hline 4 & $\begin{array}{l}4 \mathrm{X}-* \\
4 \mathrm{Y}-* \\
4 \mathrm{Z}-*\end{array}$ & $\begin{array}{l}\text { Outboard End of } \\
\text { Heater End Shell }\end{array}$ \\
\hline 5 & $\begin{array}{l}5 \mathrm{X}-* \\
5 \mathrm{Z}+*\end{array}$ & Alternator Housing 9 o'clock \\
\hline 6 & $\begin{array}{l}6 \mathrm{X}+* \\
6 \mathrm{Z}+*\end{array}$ & Alternator Housing 3 o'clock \\
\hline 7 & $7 \mathrm{Y}-*$ & Heater Housing 12 o'clock \\
\hline 8 & $8 \mathrm{Y}-*$ & Heater Housing 6 o'clock \\
\hline 9 & $\begin{array}{l}9 \mathrm{X}+* \\
9 \mathrm{Y}-*\end{array}$ & $\begin{array}{c}\text { Alternator Housing } \\
12 \text { o'clock }\end{array}$ \\
\hline 10 & $10 \mathrm{Y}-*$ & Alternator Housing 6 o'clock \\
\hline 11 & $11 \mathrm{Z}+*$ & Heater Housing 9 o'clock \\
\hline 12 & $12 \mathrm{Z}+*$ & Heater Housing 3 o'clock \\
\hline 20 & $20 \mathrm{Y}-*$ & Main Fixture \\
\hline 21 & $21 \mathrm{Y}-*$ & Auxiliary Fixture \\
\hline 22 & $\begin{array}{l}22 \mathrm{X}+* \\
22 \mathrm{Y}-* \\
22 \mathrm{Z}-*\end{array}$ & Main Fixture \\
\hline 23 & $\begin{array}{l}23 \mathrm{X}-* \\
23 \mathrm{Y}+* \\
23 \mathrm{Z}-*\end{array}$ & Auxiliary Fixture \\
\hline 30 & $\begin{array}{l}30 \mathrm{X}+* \\
30 \mathrm{Y}+*\end{array}$ & Main Fixture \\
\hline 32 & $\begin{array}{l}32 \mathrm{Y}+* * \\
32 \mathrm{Z}-* *\end{array}$ & Main Fixture \\
\hline 34 & $\begin{array}{l}34 \mathrm{Y}+* * \\
34 \mathrm{Z}-* *\end{array}$ & Main Fixture \\
\hline
\end{tabular}

* Accelerometer

** Displacement Probe

The vibration testing started in the axial axis (X, direction of the TDC's piston stroke), followed by the lateral (Y, perpendicular to the TDC's piston stroke and parallel to the slip plate). The TDC Unit \#6 was subjected to sine environments with the convertor being electrically motored, under a vibratory base-shake excitation load. These sine levels are shown in Figure 4. The data reported in this paper is derived from the $1 / 4 \mathrm{G}$ base-shake sine vibration test with the alternator motored on.

The TDC behaved linearly (with no frequency shifts of structural resonances due to input excitation level) within the range of the sine excitations used. This linearity is demonstrated by the overlap of the two Frequency Response Functions (FRF) for $1 / 8 G$ and $1 / 4 G$ sine excitation, as shown in Figure 5.

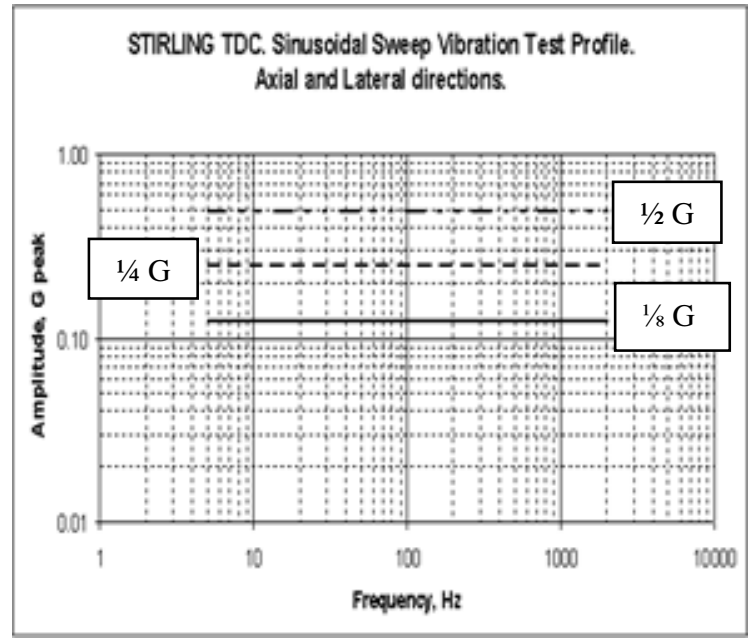

FIGURE 4. Sinusoidal Base-Shake Excitation Test Profile.

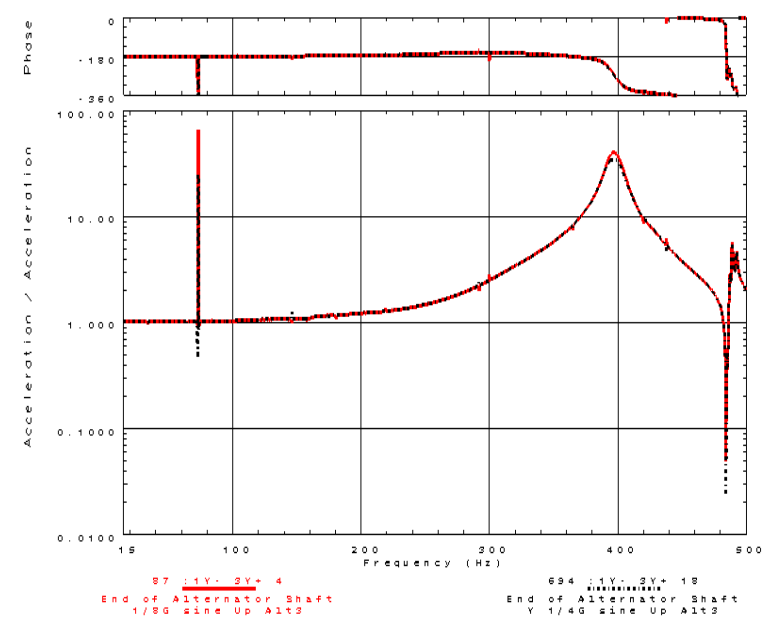

FIGURE 5. Stirling TDC Linearity Check.

\section{DATA PROCESSING}

All data was collected and post processed using a HP VXI data acquisition system and IDEAS-8 Master Series $8 \mathrm{M} 3$ software. In the final analysis, a bin width of $0.625 \mathrm{~Hz}$ was used with hanning broad window applied. The $\mathrm{H}_{1}$ Frequency Response Function (FRF) method (Equation 1) was used. This formulation, described below, minimizes the noise of the output. It is susceptible to noise on the input and underestimates the analytical system's frequency response function. In this test the only input was the signal coming from the control system and it was relatively easy to minimize the noise. Since the main objective was to identify major resonances (and not damping value or amplitude) $\mathrm{H}_{1}$ was utilized to fulfill the objective. 


$$
H_{1}=\frac{S_{y} \times S_{x}^{*}}{S_{x} \times S_{x}^{*}}=\frac{G_{y x}}{G_{x x}}
$$

Where,

$\mathrm{S}_{\mathrm{y}}(\mathrm{f})$ - linear Fourier spectrum of $\mathrm{y}(\mathrm{t})$ (time domain output of the system)

$\mathrm{S}_{\mathrm{x}}(\mathrm{f})$ - linear Fourier spectrum of $\mathrm{x}(\mathrm{t})$ (time domain input of the system)

$\mathrm{G}_{\mathrm{yx}}(\mathrm{f})-$ cross spectrum of $\mathrm{y}(\mathrm{t})$ and $\mathrm{x}(\mathrm{t})$ - complex valued

$$
\mathrm{G}_{\mathrm{xx}}(\mathrm{f}) \text { - autopower spectrum of } \mathrm{x}(\mathrm{t})
$$$$
\text { * - indicates complex conjugates }
$$

Part of the processing involved the development of a simplified model of the basic geometry of the test unit to visualize the mode shapes obtained from the FRF curve fitting analysis. This Test Display Model (TDM) (see Table 2 and Figure 6) of the Stirling TDC was used to visualize the modes and was based only on the number of accelerometers used during the test. A finite element model of the Stirling TDC was not available; therefore, a proper Test Analytical Model (TAM) was not developed.

TABLE 2. Stirling TDC Dynamic Traceline Model.

\begin{tabular}{|c|c|c|}
\hline $\begin{array}{c}\text { Traceline } \\
\#\end{array}$ & Represents & Nodes \\
\hline 2 & Alternator & $5-6,9-10$ \\
\hline 3 & $\begin{array}{c}\text { Piston Housing } \\
\text { Small Diameter }\end{array}$ & $7-8,11-12$ \\
\hline 5 & Main Fixture & 20,22 \\
\hline 6 & Auxiliary Fixture & 21,23 \\
\hline 7 & Main Fixture & 2,30 \\
\hline 8 & Piston/Mover Rod & $3,32,34$ \\
\hline 9 & TDC & $100,200,4$ \\
\hline
\end{tabular}

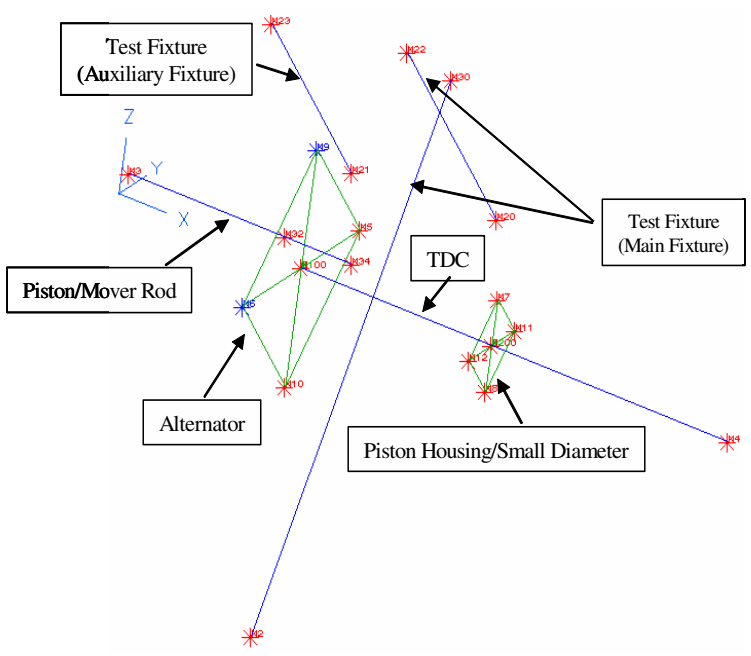

FIGURE 6. Test Display Model (TDM) of the Stirling TDC.

\section{TEST RESULTS AND DISCUSSION}

The base-shake vibration testing of the Stirling TDC Unit \#6 was conducted successfully. This was the first of two test sequences to characterize the TDC's internal dynamics. In this base-shake vibration test, the Stirling TDC was motored and the piston/mover rod was monitored with a combination of optical displacement probes (mounted to the fixtures riding on the shaker table) and accelerometers at three stations (Table 2, Traceline 8) along the rod. Double differentiation of each optical displacement probe allowed calculation of a pseudo-acceleration. The second test sequence was an impact test ${ }^{4}$ where the piston/mover rod was monitored with accelerometers at similar rod locations, as well as an additional accelerometer on the alternator flexure leaves. During impact testing, the unit was not motored. In both tests a tri-axial accelerometer mounted on the outboard tip of the piston/mover rod as well as other casing accelerometers were mounted in similar locations of the TDC for data comparison.

In the base-shake vibration test, sine input was used to excite the TDC's modes. Whereas a PCB instrumented hammer with a soft tip was used in the impact test to impart localized energy into the piston/mover rod, flexures, and stator casing to excite the modes of the TDC. Common to both tests, the Stirling TDC was tested without the alternator pressure shell to gain access to the piston/mover rod on both sides of the stator and on the outboard tip. A goal of future testing would be to gather similar data with window ports integrated onto a test alternator pressure vessel allowing the optical displacement probes to gather data while the TDC was generating power.

In both tests, the number and location of the sensors limited the observable results, but sufficient information existed to describe some of the Stirling TDC principal modes, in the plateau region (50 to $250 \mathrm{~Hz}$ ) of the Design/Qualification specification (see Figure 2).

In these base-shake sine vibration tests, a number of principal modes, were excited by both axial and lateral shakes (i.e., $\mathrm{X}$ and $\mathrm{Y}$-axes input) (see compilation in Tables 3 and 4 respectively). While the shake directions were orthogonal (i.e., in different directions), energy put in the system should net similar mode response and/or shapes as energy is a scalar (ideally non-directional). To check these properties, the modes are compared mathematically (i.e., X-axis input vs. Y-axis input test) via a Modal Assurance Criteria (MAC) Matrix, as shown in Figure 7. The MAC is an 
unweighted numerical procedure to quantify the linear independence between two mode shapes. As the MAC value approaches zero, the two compared shapes are linearly independent or not related. As the MAC value approaches one, the two mode shapes reflect each other and most likely are the same. The method has several limitations. If an appropriate mass representation is available, then the calculated modal response can be mass weighted and error or "noise" in the shape can be reduced. Or as stated before, observability in this test is limited by the available instrumentation. In other words, spatially under-sampling of the measured mode can skew the numerical results. Therefore, the interpretation of the MAC may be limited. In short, the sparse accelerometer distribution limits our insight into the modal data. Additionally, the lack of a pre-test Finite Element Model (FEM) predictions limited the optimal selection of accelerometer locations and did not allow for the natural generation of an appropriate mass matrix for orthogonality measures.

For example, the MAC indicates that the $74.7 \mathrm{~Hz}$ and 159.7 Hz modes have similar mode shapes (see Figure 7). However, the Frequency Response Function (FRF) clearly indicates two different modes (see Figure 8). The MAC is unable to differentiate the two distinct mode shapes due to the lack of instrumentation.

TABLE 3. Modes Excited By X-Axis Input.

\begin{tabular}{|c|l|c|}
\hline $\begin{array}{c}\text { Frequency } \\
\text { Hz }\end{array}$ & \multicolumn{1}{|c|}{ Mode Description } & $\begin{array}{c}\text { \% Critical } \\
\text { Damping }\end{array}$ \\
\hline 74.7 & $\begin{array}{l}\text { Piston/Mover Rod combined } \\
\text { axial and bending response } \\
\text { in both Y and Z-axes }\end{array}$ & 1.1 \\
\hline 158.3 & Z-axis mode (Table mode?) & 1.93 \\
\hline 400.7 & $\begin{array}{l}\text { Piston/Mover Rod primarily } \\
\text { Z-axis cantilever/radial } \\
\text { response }\end{array}$ & 1.39 \\
\hline 569.3 & $\begin{array}{l}\text { Internal mode, not enough } \\
\text { information }\end{array}$ & 0.03 \\
\hline
\end{tabular}

TABLE 4. Modes Excited By Y-Axis Input.

\begin{tabular}{|c|l|c|}
\hline $\begin{array}{c}\text { Frequency } \\
\text { Hz }\end{array}$ & \multicolumn{1}{|c|}{ Mode Description } & $\begin{array}{c}\text { \% Critical } \\
\text { Damping }\end{array}$ \\
\hline 159.7 & Z-axis mode (Table mode?) & 1.66 \\
\hline 394.7 & $\begin{array}{l}\text { Piston/Mover Rod primarily } \\
\text { Y-axis cantilever/radial } \\
\text { response }\end{array}$ & 1.47 \\
\hline 400.2 & $\begin{array}{l}\text { Piston/Mover Rod primarily } \\
\text { Z-axis cantilever/radial } \\
\text { response }\end{array}$ & 1.40 \\
\hline 525.3 & $\begin{array}{l}\text { Internal mode, not enough } \\
\text { information }\end{array}$ & 3.87 \\
\hline
\end{tabular}

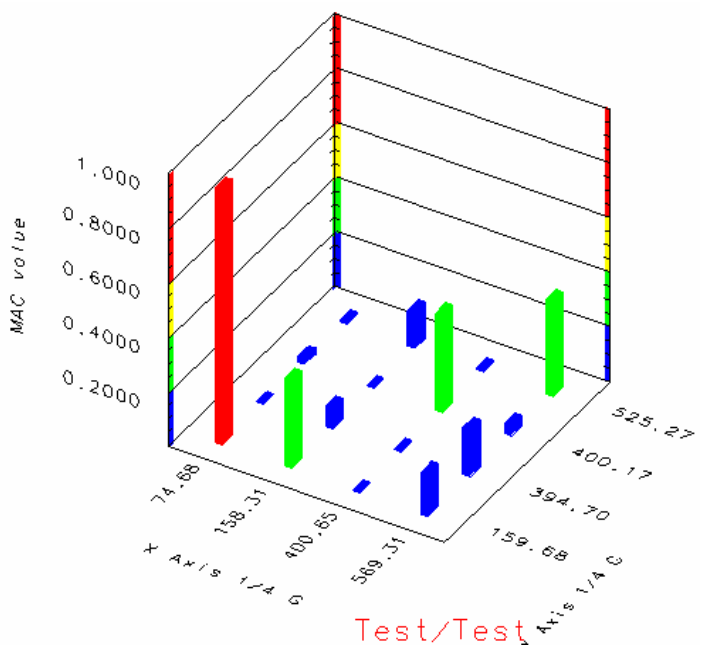

FIGURE 7. MAC Matrix of X-Axis vs. Y-Axis Input.

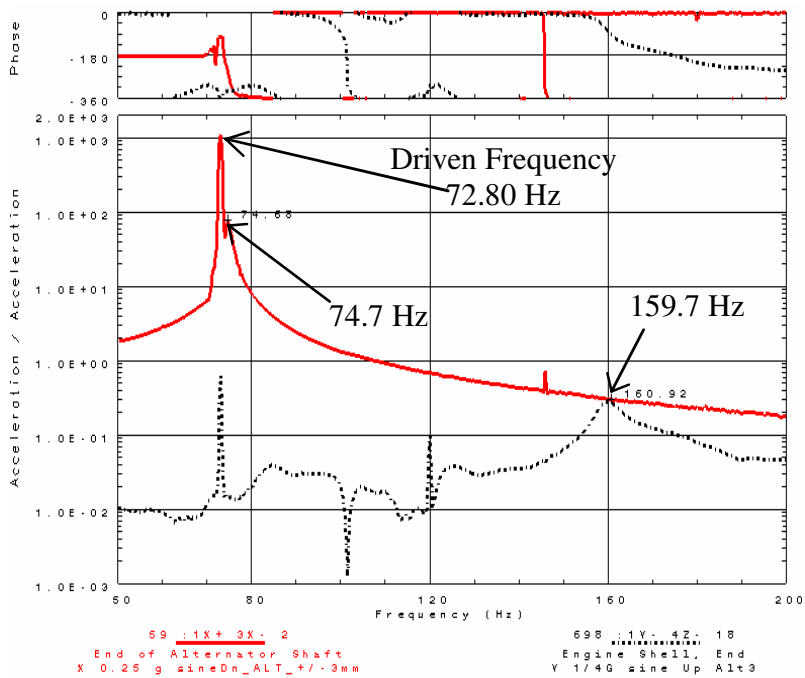

FIGURE 8. $74.7 \mathrm{~Hz}$ Vs $159.7 \mathrm{~Hz}$

Frequency Response Function Comparison.

The MAC indicates dependency of three other mode pairs. The $158.3 \mathrm{~Hz}$ mode (excited by X-axis input) appears to be the same mode as the $159.7 \mathrm{~Hz}$ (excited by the Y-axis input) mode. Similarly the $400.7 \mathrm{~Hz}$ mode (X-axis excitation) and the $400.2 \mathrm{~Hz}$ mode (Y-axis excitation) are likely the same mode. Finally, due to their distinct mode shapes the $569.3 \mathrm{~Hz}$ mode (X-axis excitation) and the $525.3 \mathrm{~Hz}$ mode (Y-axis excitation) are believed to be different modes despite the MAC information.

The base-shake testing showed two modes between 50 and $250 \mathrm{~Hz}$, at approximately $75 \mathrm{~Hz}$ and $159 \mathrm{~Hz}$. These results were discerned through the Test Display Model. The first frequency $(74.7 \mathrm{~Hz})$ was directly 
linked to the motoring of the linear alternator's piston/mover rod (see Figure 9). The acceleration data from the optical displacement probes (after it was differentiated twice and properly scaled) was comparable to the impact acceleration data (i.e., gathered from additional accelerometers on the rod and flexures used in the impact test). This pseudoacceleration data provided critical insight to the effects of motoring the Stirling. At the driven frequency of $74.7 \mathrm{~Hz}$, bending motion was observed by the probes in both axes ( $\mathrm{Y}$ and $\mathrm{Z}$ ) (see Figure 10). Looking at the derived mode shape, it was concluded that the piston mover rod went through a combined axial (translational) and bending motion in both the $\mathrm{Y}$ and Z-axes. This behavior of the shaft at $74.7 \mathrm{~Hz}$ is believed to occur due to the interaction of the flexures on the shaft as it moves back and forth. Figure 10 also shows the driven frequency of the alternator to be around $73 \mathrm{~Hz}$; harmonics of this frequency $(146 \mathrm{~Hz}$, $219 \mathrm{~Hz}$ ) are shown throughout the data.

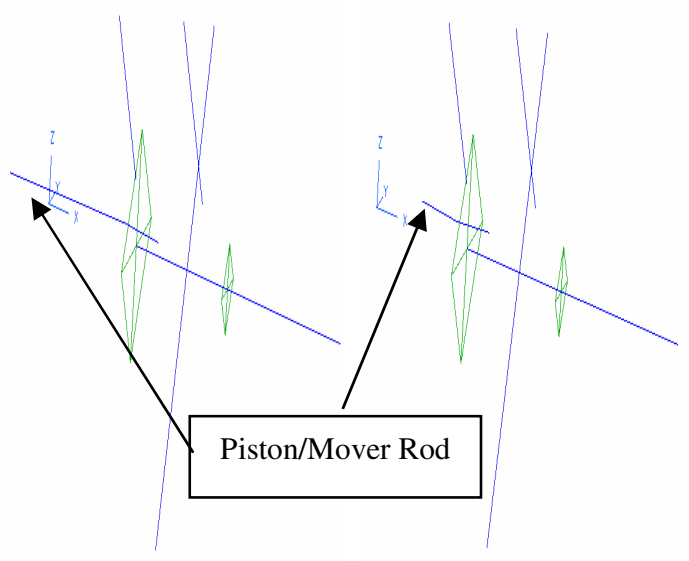

FIGURE 9. Two Snapshots of the $74.7 \mathrm{~Hz}$ Mode Shape Showing Piston/Mover Rod Motion.

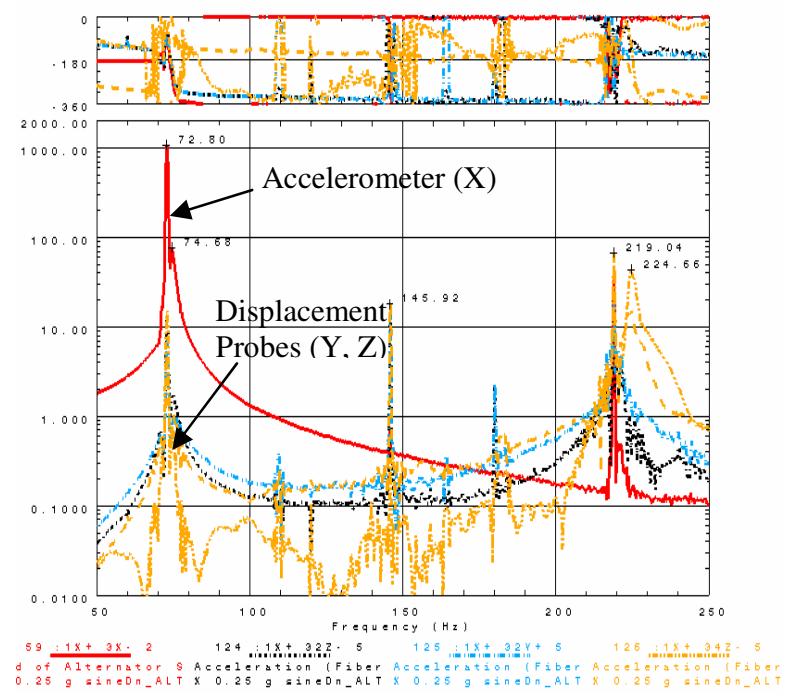

FIGURE 10. Frequency Response Function Illustrating X, Y and Z Motion of the Piston/Mover Rod at $74.7 \mathrm{~Hz}$.
A comparison of an identically located $\mathrm{X}$-axis accelerometer, mounted on the outboard end of the piston/mover rod, for both the base-shake vibration (TDC motored) and the impact test (TDC not motored) is shown by the FRFs in Figure 11. The data is similar between these two tests with the primary exception that the TDC's fundamental frequency observed in the baseshake vibration test is about $5 \mathrm{~Hz}$ higher than the measured fundamental frequency in the impact test. This is due to the motoring condition of the TDC. As the TDC is motored (as in the base-shake vibration test), the stiffness of the system increases due to the flexures getting stiffer (with increasing deflection) as well as the addition of the motor's electro-motive force (emf). This is a similar concept of the operation Stirling TDC's operation frequency increasing due to the addition of the internal gas spring dynamics.

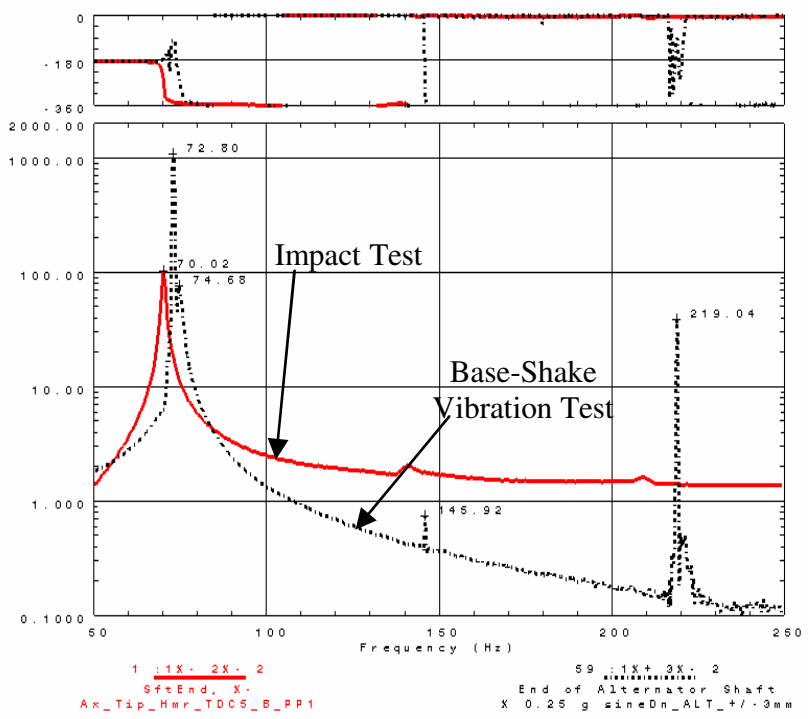

FIGURE 11. FRFs of Outboard End of the Piston/Mover Rod X-Axis Accelerometer for Impact and Base-Shake Vibration Tests.

The second, very low magnitude, mode found in the plateau region of interest was approximately $159 \mathrm{~Hz}$. It was determined to be related to the Z-response as indicated in the $\mathrm{FRF}(\mathrm{s})$ of nearly all the $\mathrm{Z}$ accelerometers for both $\mathrm{X}$ and $\mathrm{Y}$-axes input base-shake vibration testing (Figures 12 and 13). Due to limited data (number of instrumentation) a clear identification of the mode could not be defined. Since this mode was not excited in the impact test it is suspected that it might be related to the shaker table motion (excited during the base-shake vibration test). 


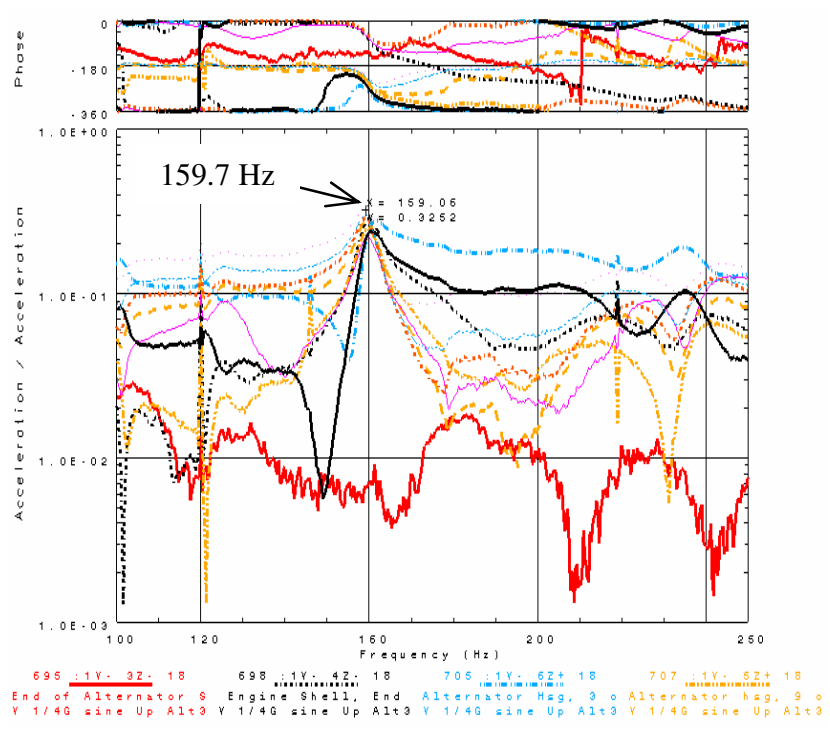

FIGURE 12. Z Responses for X-Axis Input Base-Shake.

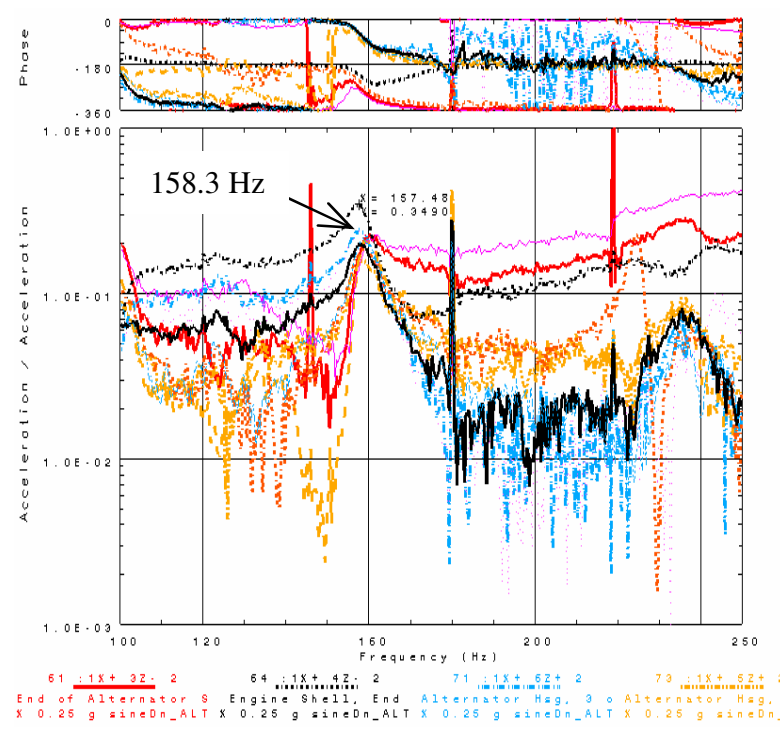

FIGURE 13. Z Responses for Y-Axis Input Base-Shake.

The principal dynamics modes of the TDC observed in both the base-shake vibration test and the hammer impact test were: (a) Piston/Mover Rod combined axial and bending response $(\sim 75 \mathrm{~Hz})$, (b) the Piston/Mover Rod Z-axis cantilever/radial response $(\sim 400 \mathrm{~Hz})$, and (c) the Piston/Mover Rod Y-axis cantilever/radial response $(\sim 395 \mathrm{~Hz})$.

The direct excitation used in the impact test provided a $134 \mathrm{~Hz}$ mode that was estimated to be a highly damped casing/displacer mode. This mode was not observed in the sine base-shake vibration test. As mentioned previously the TDC was motored on during the baseshake vibration testing increasing the stiffness and damping on the system which probably resulted in less dynamics motion of the casing/displacer.

Data from the probes located on the auxiliary fixture also showed a resonance approximated at $224 \mathrm{~Hz}$. This frequency was concluded to be an auxiliary test fixture local mode since it was only noticed on this fixture.

\section{CONCLUSIONS}

In February 2001, a motored Stirling TDC without its alternator pressure vessel was subjected to sine environments via base-shake input at NASA GRC's SDL. The vibration tests were successfully performed as it met the test objective to provide insight to the Stirling TDC's dynamics. Optical displacement probes and acceleration sensors were mounted throughout the TDC and as a result of this test, some of the Stirling TDC principal modes were identified (see Tables 3 and 4). In general the results were restricted by the number of sensors and the absence of an analytical Test Analysis Model. The Test Display Model consisting of tracelines and elements (Table 2, Figure 6) was illustrative of the reported phenomena, but there is still a fair amount of conjecture in the interpretation of the results due to limits in the observability criterion.

There were only two modes of the test item with frequencies in the primary plateau region of interest $(50-250 \mathrm{~Hz})$ of Figure 2; the $74.7 \mathrm{~Hz}$ piston/mover rod combined response, and the Z-axis shaker table related mode at $158 \mathrm{~Hz}$ mode. The base-shake vibration test results increased the confidence level of the conclusions obtained during the impact test ${ }^{4}$. The $74.7 \mathrm{~Hz}$ piston/mover rod combined response (axial and bending) phenomenon noticed in the impact test was once again noticed on the base-shake vibration test data but in this case the piston/mover rod was instrumented at different locations providing a better understanding of the dynamics of the linear alternator. The data reassures that the $74.7 \mathrm{~Hz}$ mode is a combination of an axial motion (translational) and bending motion in both the $\mathrm{Y}$ and Z-axes (Figure 9). It is believed that the combined flexural response with the axial response at this frequency may produce friction and leakage losses. This response phenomenon may provide a possible explanation of the observed drop of power during the lateral vibration testing at high vibration levels due to the loss of clearance in tight tolerance areas of the $\mathrm{TDC}^{2,3}$. The remaining modes found outside the initial plateau region $(>250 \mathrm{~Hz})$ were noted to complete the description of the TDC's structural response; however 
these modes are not as significant because they will not be excited to the same high qualification input levels.

Even though the vibration test (February 2001) and the impact test (May 2001) did not have sensors at the same exact locations (other than at the end of the piston/mover rod) a limited comparison between tests was made. Both test methods allowed modal extraction of many of the principal modes of the TDC. It was observed that the TDC's operational (i.e., motored) fundamental frequency respectively increases about $5 \mathrm{~Hz}$ due to motoring versus the non-motored loading conditions. As the TDC is motored, the stiffness of the system increases due to increased flexure stiffness and the addition of the motor's electro-motive force (emf).

For the Stirling TDC test program, the impact test followed the base-shake vibration test, and thus it had the advantage of having extra internal sensors. This additional information facilitated the interpretation of the dynamics of the TDC. Nevertheless, both tests provided a means to characterize the major structural resonances of the TDC. However, impact testing allows direct excitation which may optimize the excitation of some local modes.

In closing, these conclusions must be considered in light of the TDC's mounting configuration. The TDC was mounted by the large flange of the piston housing for our tests and the results would be affected by other choices of mounting configurations. Lastly, the implementation of system mounting frequency (i.e., where the multiple TDC's are combined into a single power unit) may have an effect on these results unless clearly decoupled (e.g. a fundamental system mounting frequency of $30-40 \mathrm{~Hz}$ ).

\section{REFERENCES}

1. Schreiber, J. G., and Thieme, L. G., "Update on the Stirling Convertor Testing and Technology Development at NASA GRC," in Proceedings of the Intersociety Energy Conversion Engineering Conference, Savannah, Georgia, July 29-August 2, 2001, IECEC2001-CT-26.

2. Goodnight, T.W., Hughes W.O., and McNelis, M.E., "Dynamic Capability of an Operating Stirling Convertor," in Proceedings of the $35^{\text {th }}$ Intersociety Energy Conversion Engineering Conference, Las Vegas, NV, July 24-28, 2000, NASA/TM-2000210527, AIAA-2000-2839.

3. Hughes, W.O., McNelis, M.E., and Goodnight, T.W., "Vibration Testing of on Operating Convertor," in Proceedings of the Seventh International Congress on Sound and Vibration, Garmisch-Partenkirchen, Germany, July 4-7, 2000, NASA/TM-2000-210526.

4. Suárez, V., Goodnight, T.W., Hughes, W.O., and Samorezov, S., "Impact Testing of a Stirling Convertor's Linear Alternator," in Proceedings of the Space Technology and Applications International Forum (STAIF-2002), Albuquerque, New Mexico, February 3-7, 2002, NASA/TM-2002-211342. 
Public reporting burden for this collection of information is estimated to average 1 hour per response, including the time for reviewing instructions, searching existing data sources, gathering and maintaining the data needed, and completing and reviewing the collection of information. Send comments regarding this burden estimate or any other aspect of this collection of information, including suggestions for reducing this burden, to Washington Headquarters Services, Directorate for Information Operations and Reports, 1215 Jefferson Davis Highway, Suite 1204, Arlington, VA 22202-4302, and to the Office of Management and Budget, Paperwork Reduction Project (0704-0188), Washington, DC 20503.

\begin{tabular}{|l|l|l|}
\hline 1. AGENCY USE ONLY (Leave blank) & $\begin{array}{c}\text { 2. REPORT DATE } \\
\text { November } 2003\end{array}$ & $\begin{array}{r}\text { 3. REPORT TYPE AND DATES COVERED } \\
\text { Technical Memorandum }\end{array}$ \\
\hline
\end{tabular}

\section{TITLE AND SUBTITLE}

Vibration Modal Characterization of a Stirling Convertor via Base-Shake Excitation

\section{AUTHOR(S)}

Vicente J. Suárez, Thomas W. Goodnight, William O. Hughes, and Sergey Samorezov

\section{PERFORMING ORGANIZATION NAME(S) AND ADDRESS(ES)}

National Aeronautics and Space Administration

John H. Glenn Research Center at Lewis Field

Cleveland, Ohio 44135-3191

\section{FUNDING NUMBERS}

WBS-22-979-30-01

\section{SPONSORING/MONITORING AGENCY NAME(S) AND ADDRESS(ES)}

National Aeronautics and Space Administration

Washington, DC 20546-0001
8. PERFORMING ORGANIZATION REPORT NUMBER

E-14017

\section{SUPPLEMENTARY NOTES}

Prepared for the First International Energy Conversion Engineering Conference cosponsored by the American Institute of Aeronautics and Astronautics (AIAA), the American Society of Mechanical Engineers (ASME), and the Institute of Electrical and Electronics Engineers (IEEE), Portsmouth, Virginia, August 17-21, 2003. Vicente J. Suárez, Thomas W. Goodnight, and William O. Hughes, NASA Glenn Research Center; Sergey Samorezov, ZIN Technologies, Inc., Cleveland, Ohio 44142. Responsible person, Vincente J. Sáurez, organization code 7735, 216-433-8939.

12a. DISTRIBUTION/AVAILABILITY STATEMENT 12b. DISTRIBUTION CODE

Unclassified - Unlimited

Subject Categories: 18, 20, and 44

Distribution: Nonstandard

Available electronically at http://gltrs.grc.nasa.gov

This publication is available from the NASA Center for AeroSpace Information, 301-621-0390.

\section{ABSTRACT (Maximum 200 words)}

The U.S. Department of Energy (DOE), Lockheed Martin (LM), Stirling Technology Company (STC), and NASA John H. Glenn Research Center (GRC) are currently developing a high-efficiency Stirling convertor for use in a Stirling Radioisotope Generator (SRG). NASA and DOE have identified the SRG for potential use as an advanced power system for future NASA Space Science missions, providing spacecraft onboard electric power for deep space missions and power for unmanned Mars rovers. Low-level, base-shake sine vibration tests were conducted on the Stirling Technology Demonstration Convertor (TDC), at NASA GRC's Structural Dynamics Laboratory, in February 2001, as part of the development of this Stirling technology. The purpose of these tests was to provide a better understanding of the TDC's internal dynamic response to external vibratory base excitations. The knowledge obtained can therein be used to help explain the success that the TDC enjoyed in its previous random vibration qualification tests (December 1999). This explanation focuses on the TDC's internal dynamic characteristics in the 50 to $250 \mathrm{~Hz}$ frequency range, which corresponds to the maximum input levels of its qualification random vibration test specification. The internal dynamic structural characteristics of the TDC have now been measured in two separate tests under different motoring and dynamic loading conditions: (1) with the convertor being electrically motored, under a vibratory base-shake excitation load; and (2) with the convertor turned off, and its alternator internals undergoing dynamic excitation via hammer impact loading. This paper addresses the test setup, procedure, and results of the base-shake vibration testing conducted on the motored TDC, and will compare these results with those results obtained from the dynamic impact tests (May 2001) on the non-motored TDC.

\section{SUBJECT TERMS}

Structural vibration; Vibration testing; Stirling engines; Spacecraft power systems

\begin{tabular}{|c|c|c|}
\hline $\begin{array}{c}\text { 17. SECURITY CLASSIFICATION } \\
\text { OF REPORT } \\
\text { Unclassified }\end{array}$ & $\begin{array}{c}\text { 18. SECURITY CLASSIFICATION } \\
\text { OF THIS PAGE } \\
\text { Unclassified }\end{array}$ & $\begin{array}{c}\text { 19. SECURITY CLASSIFICATION } \\
\text { OF ABSTRACT } \\
\text { Unclassified }\end{array}$ \\
\hline
\end{tabular}

